Published in final edited form as:

Phytochemistry. 2014 February ; 98: 232-235. doi:10.1016/j.phytochem.2013.11.005.

\title{
Withanolides from Jaborosa caulescens var. bipinnatifida
}

\author{
Huaping Zhang ${ }^{\mathrm{a}}$, Cong-Mei Cao ${ }^{\mathrm{a}}$, Robert J. Gallagher ${ }^{\mathrm{a}}$, Victor W. Day ${ }^{\mathrm{b}}$, Gloria \\ Montenegro $^{c}$, and Barbara N. Timmermann ${ }^{a,{ }^{*}}$ \\ aDepartment of Medicinal Chemistry, School of Pharmacy, University of Kansas, Lawrence, KS \\ 66045, USA \\ bThe Small-Molecule X-ray Crystallography Laboratory, University of Kansas, Lawrence, KS \\ 66047, USA
}

'Facultad de Agronomia e Ingenieria Forestal, Universidad Católica de Chile, Vicuna Mackenna 4860, Santiago, Chile

\begin{abstract}
Two new withanolides 2,3-dihydrotrechonolide A (1) and 2,3-dihydro-21-hydroxytrechonolide A (2) were isolated along with two known withanolides trechonolide A (3) and jaborosalactone 39

(4) from Jaborosa caulescens var. bipinnatifida (Solanaceae). The structures of 1-2 were elucidated through 2D NMR and other spectroscopic techniques. In addition, the structure of withanolide $\mathbf{1}$ was confirmed by X-ray crystallographic analysis.
\end{abstract}

\section{Keywords}

2, 3-dihydrotrechonolide A; 2, 3-dihydro-21-hydroxytrechonolide A; Withanolide; Jaborosa caulescens var. bipinnatifida; Solanaceae

\section{Introduction}

Withanolides are a group of modified, highly-oxygenated $\mathrm{C}_{28}$ ergostane-type steroids, present primarily in several genera of the Solanaceae which include Acnistus, Datura, Dunalia, Jaborosa, Physalis, Vassobia and Withania. In recent years, these $\mathrm{C}_{28}$ steroids have attracted attention due to their structural diversity as well as their biological activities including promising antitumor, insecticidal and phytotoxic capacities (Chen et al., 2011; Misico et al., 2011; Zhang et al., 2012a). Recently we reported the isolation and characterization of a series of withanolides with structural variations in the steroidal nucleus and the side chain from Datura wrightii (Zhang et al., 2013), Physalis longifolia (Zhang et al., 2011; Zhang et al., 2012b), Vassobia brevifolia (Samadi et al., 2010), and Withania somnifera (Tong et al., 2011). There are a total of 23 Jaborosa species which are mostly

\footnotetext{
(C) 2013 Elsevier Ltd. All rights reserved.

*To whom corresponding should be addressed. Tel: +01-785-864-4844. Fax: +01-785-864-5326. btimmer@ku.edu. Supporting Information

${ }^{1} \mathrm{H},{ }^{13} \mathrm{C}$ (APT), and 2D NMR spectra of withanolides $\mathbf{1}$ and $\mathbf{2}$ are available. Crystallographic data for the structure of $\mathbf{1}$ as reported in this paper were deposited with the Cambridge Crystallographic Data Centre, under reference number CCDC 943258. Copies of the data can be obtained, free of charge, on application to the Director, CCDC, 12 Union Road, Cambridge CB2 1EZ, UK (fax: +44(0)1223-336033 or e-mail: deposit@ccdc.cam.ac.uk).

Publisher's Disclaimer: This is a PDF file of an unedited manuscript that has been accepted for publication. As a service to our customers we are providing this early version of the manuscript. The manuscript will undergo copyediting, typesetting, and review of the resulting proof before it is published in its final citable form. Please note that during the production process errorsmaybe discovered which could affect the content, and all legal disclaimers that apply to the journal pertain.
} 
distributed throughout South America and contain abundant and diverse withanolides (Misico et al., 2011). In continuing our withanolide research, we examined the aboveground biomass of the Chilean perennial shrub Jaborosa caulescens var. bipinnatifida Gillies \& Hook. Herein we report the isolation and structure elucidation of two new withanolides (1 and $\mathbf{2}$ ) as well as two known withanolides ( $\mathbf{3}$ and $\mathbf{4})$ from the species.

\section{Results and discussion}

Compounds 1-4 were isolated from the $\mathrm{CH}_{2} \mathrm{Cl}_{2}$ partition phase of the $\mathrm{CH}_{2} \mathrm{Cl}_{2}-\mathrm{MeOH}(1: 1)$ extract of J. caulescens var. bipinnatifida (see Experimental section). The molecular formula of the major component 1 was determined to be $\mathrm{C}_{28} \mathrm{H}_{38} \mathrm{O}_{7}$ by HRESIMS and NMR experiments, equating to ten double-bond equivalents. The IR absorptions of 1 revealed the presence of hydroxyl $\left(3328 \mathrm{~cm}^{-1}\right)$, ester $\left(1748 \mathrm{~cm}^{-1}\right)$ and keto $\left(1712 \mathrm{~cm}^{-1}\right)$ groups. The ${ }^{1} \mathrm{H}$ NMR spectrum (Table 1) showed the presence of five methyl groups at $\delta_{\mathrm{H}} 0.97(3 \mathrm{H}, \mathrm{s}), 1.00$ $(3 \mathrm{H}, \mathrm{d}, J=6.7 \mathrm{~Hz}), 1.07(3 \mathrm{H}, \mathrm{s}), 1.77(3 \mathrm{H}, \mathrm{s})$, and $1.89(3 \mathrm{H}, \mathrm{s})$; three protons attached to oxygenated carbons at $\delta_{\mathrm{H}} 3.12(1 \mathrm{H}$, brs $), 3.95(1 \mathrm{H}, \mathrm{dd}, J=11.1,1.9 \mathrm{~Hz}), 4.82(1 \mathrm{H}, \mathrm{s})$. The ${ }^{13} \mathrm{C}$ NMR (APT) and HSQC spectra for 1 (Table 1) displayed 28 carbon signals differentiated as five $\mathrm{CH}_{3}$, seven $\mathrm{CH}_{2}$, seven $\mathrm{CH}$ (including three oxygenated at $\delta_{\mathrm{C}} 60.2$, 68.8 , and 82.4), and nine $\mathrm{C}$ (including a keto carbonyl at $\delta_{\mathrm{C}} 213.2$, an ester carbonyl at $\delta_{\mathrm{C}}$ 175.2, two olefinic at $\delta_{\mathrm{C}} 157.3$ and 123.8 , an hemiketal or ketal at $\delta_{\mathrm{C}} 98.6$, as well as two oxygenated at $\delta_{\mathrm{C}} 80.5$ and 64.1) groups, corresponding to $\mathrm{C}_{28} \mathrm{H}_{36}$. The remaining two hydrogen atoms were therefore assigned as two $\mathrm{OH}$ groups, indicating that seven rings must be present in the structure.

The NMR data of 1 closely resembled those of trechonolide A (3) (Figure 1), a seven-ringed withanolide first reported in Jaborosa laciniata (syn: Trechonaetes laciniata) (Lavie et al., 1987). Compounds $\mathbf{1}$ and $\mathbf{3}$ were found to contain identical $\alpha, \beta$-unsaturated $\gamma$-lactone units in the side chain [two vinylic methyl groups at $\delta_{\mathrm{H}-27} 1.77$ and $\delta_{\mathrm{H}-28} 1.89$ (each $3 \mathrm{H}$, s), one oxygenated methine group at $\delta_{\mathrm{H}-23} 4.82(1 \mathrm{H}, \mathrm{s})$; and $\delta_{\mathrm{C}-26} 175.2(\mathrm{C}), \delta_{\mathrm{C}-24} 157.3(\mathrm{C}), \delta_{\mathrm{C}-25}$ $123.8(\mathrm{C}), \delta_{\mathrm{C}-23} 82.4(\mathrm{CH}), \delta_{\mathrm{C}-28} 12.0\left(\mathrm{CH}_{3}\right)$, and $\left.\delta_{\mathrm{C}-27} 8.4\left(\mathrm{CH}_{3}\right)\right]$, a hemiketal bridge formed by the 22-hydroxyl group and a ketone at $\mathrm{C}-12$ to result in a six-membered ring with a $\beta$-oriented hydroxyl at C-12 [ $\delta_{\mathrm{H}-22} 3.95(1 \mathrm{H}, \mathrm{dd}, J=11.1,1.9 \mathrm{~Hz}), \delta_{\mathrm{H}-21} 1.00(3 \mathrm{H}, \mathrm{d}, J=$ $6.7 \mathrm{~Hz}) ; \delta_{\mathrm{C}-22} 68.8(\mathrm{CH}), \delta_{\mathrm{C}-12} 98.6(\mathrm{C}), \delta_{\mathrm{C}-17} 80.5(\mathrm{C})$, and $\left.\delta_{\mathrm{C}-21} 10.2\left(\mathrm{CH}_{3}\right)\right]$, as well as a $5 \beta, 6 \beta$-epoxy group $\left[\delta_{\mathrm{H}-6} 3.12(1 \mathrm{H}, \mathrm{brs}), \delta_{\mathrm{C}-5} 64.1(\mathrm{C})\right.$ and $\left.\delta_{\mathrm{C}-6} 60.2(\mathrm{CH})\right]$.

The main differences between $\mathbf{1}$ and $\mathbf{3}$ were observed within the A ring moiety of the steroid nucleus. The ${ }^{1} \mathrm{H}$ NMR of compound 1 revealed the absence of the olefinic protons pertaining to the conjugated 1-oxo-2-ene moiety observed in 3. Instead, the ${ }^{13} \mathrm{C}$ NMR and HSQC of 1 showed signals for an isolated keto $\left(\delta_{\mathrm{C}} 213.2\right)$ and two extra methylenes [ $\delta_{\mathrm{C}}$ $34.2\left(\mathrm{CH}_{2}\right)$ corresponding to $\delta_{\mathrm{H}} 2.64(1 \mathrm{H}$, ddd, $J=14.5,9.6,6.2 \mathrm{~Hz})$ and $2.22(1 \mathrm{H}$, ddd, $J=$ $14.5,8.7,5.3 \mathrm{~Hz})$; and $\delta_{\mathrm{C}} 17.7\left(\mathrm{CH}_{2}\right)$ corresponding to $\delta_{\mathrm{H}} 1.91(1 \mathrm{H}, \mathrm{m})$ and $\left.1.88(1 \mathrm{H}, \mathrm{m})\right]$ groups. These observations suggested compound $\mathbf{1}$ was 2,3-dihydrotrechonolide $\mathrm{A}$. This was further supported by ${ }^{1} \mathrm{H}_{-}{ }^{1} \mathrm{H}$ COSY fragment of- $\mathrm{C}(2) \mathrm{H}_{2}-\mathrm{C}(3) \mathrm{H}_{2}-\mathrm{C}(4) \mathrm{H}_{2}$-; the chemical shift values of $\mathrm{H}_{2}-2$ [ $\delta_{\mathrm{H}} 2.64(1 \mathrm{H}$, ddd, $J=14.5,9.6,6.2 \mathrm{~Hz})$ and $2.22(1 \mathrm{H}$, ddd, $J=14.5,8.7,5.3$ $\mathrm{Hz})]$; the $\mathrm{HMBC}$ correlations between $\mathrm{H}_{2}-2, \mathrm{H}-3\left(\delta_{\mathrm{H}} 1.88,1 \mathrm{H}, \mathrm{m}\right)$ and $\mathrm{C}-1\left(\delta_{\mathrm{C}} 213.2\right)$; as well as the superimposable NMR signals for the moieties of rings A and B observed in both 1 and jaborosalactone 39 (4), reported from the same species (Nicotra et al., 2007).

Finally, the structure of $\mathbf{1}$ was confirmed through a single-crystal X-ray diffraction experiment (Figure 2). Thus, withanolide 1 was determined as 2,3-dihydrotrechonolide A. The full assignments of NMR data of $\mathbf{1}$ (Table 1) were obtained by 2D-NMR including ${ }^{1} \mathrm{H}-{ }^{1} \mathrm{H}$ COSY, multiplicity edited-HSQC, HMBC and ROESY experiments. 
The molecular formula of compound 2 was determined to be $\mathrm{C}_{28} \mathrm{H}_{38} \mathrm{O}_{8}$ by HRESIMS and NMR experiments. Its IR absorptions and NMR data (Table 1) resemble those of $\mathbf{1}$. The main differences between $\mathbf{2}$ and $\mathbf{1}$ were observed in the C-21 NMR signals. The absent C-21 methyl signal along with the appearance of a pair of double doublets at $\delta_{\mathrm{H}} 4.14(1 \mathrm{H}, \mathrm{dd}, J=$ $12.4,1.4 \mathrm{~Hz})$ and $3.93(1 \mathrm{H}, \mathrm{dd}, J=12.4,3.9 \mathrm{~Hz})$ in compound 2 suggested that 2 was a 21hydroxy derivative of $\mathbf{1}$. This observation was supported by the resonance signals of C-21 $\left(\mathrm{CH}_{2}, \delta_{\mathrm{C}} 59.9, \delta_{\mathrm{H}} 4.14\right.$ and 3.93), ${ }^{1} \mathrm{H}-{ }^{1} \mathrm{H}$ COSY fragment of- $\mathrm{C}(21) \mathrm{H}_{2}-\mathrm{C}(20) \mathrm{H}-\mathrm{C}(22) \mathrm{H}-$ $\mathrm{CH}(23)-\left[\mathrm{H}_{2}-21 \delta_{\mathrm{H}} 4.14(1 \mathrm{H}, \mathrm{dd}, J=12.4,1.4 \mathrm{~Hz})\right.$ and $3.93(1 \mathrm{H}, \mathrm{dd}, J=12.4,3.9 \mathrm{~Hz}) ; \mathrm{H}-20$ $\delta_{\mathrm{H}} 2.19(1 \mathrm{H}, \mathrm{ddd}, J=11.3,3.9,1.4 \mathrm{~Hz}) ; \mathrm{H}-22 \delta_{\mathrm{H}} 4.69(1 \mathrm{H}, \mathrm{dd}, J=11.3,1.9 \mathrm{~Hz}) ;$ and $\mathrm{H}-23$ $\left.\delta_{\mathrm{H}} 5.08(1 \mathrm{H}, \mathrm{s})\right]$. It was confirmed by $\mathrm{HMBC}$ correlations between $\mathrm{H}_{2}-21\left(\delta_{\mathrm{H}} 4.14\right.$ and 3.93) and C-20 $\left(\delta_{\mathrm{C}} 59.9\right), \mathrm{C}-22\left(\delta_{\mathrm{C}} 64.7\right)$, and C-17 $\left(\delta_{\mathrm{C}} 83.0\right)$, as well as the superimposable NMR signals for the side chain of $\mathbf{1}$ and jaborosalactone 41, reported from the same species (Nicotra et al., 2007). Thus, withanolide 2 was determined as 2,3- dihydro-21hydroxytrechonolide A.

Withanolides 1-4 share a distinct structural moiety, a hemiketal bridge, that has only been reported in withanolides from the Solanaceous genera Deprea (Su et al., 2003) and Jaborosa (Misico et al., 2011). This structural moiety is formed by the interaction of 22-hydroxyl (or 21- hydroxyl) and C-12 ketone groups, resulting in a six-membered ring composed of C-12, $13,17,20,22$ (or 21) and an oxygen atom. In addition, compound $\mathbf{4}$ contains a commonly encountered $\delta$ - lactone in the side chain, whereas compounds 1-3 possess a less prevalent $\gamma$ lactone structural moiety that is confined to the genera Deprea, Jaborosa, and Physalis. In conclusion, compounds $\mathbf{1}$ and $\mathbf{2}$ are two new additions to this limited structural sub-type of withanolides.

\section{Experimental}

\subsection{General experimental procedures}

Optical rotations were measured with a Rudolph RS Autopol IV automatic polarimeter. IR data were obtained with a Thermo Nicolet Avatar 380 FT-IR spectrometer. NMR spectra were recorded with a Bruker AV-400 or AV-500 instrument with a cryoprobe for ${ }^{1} \mathrm{H}$, APT ${ }^{13} \mathrm{C}$, COSY, HSQC, HMBC, and ROESY. Chemical shift values are given in $\delta(\mathrm{ppm})$ using the peak signals of the solvent $\mathrm{CDCl}_{3}\left(\delta_{\mathrm{H}} 7.26\right.$ and $\left.\delta_{\mathrm{C}} 77.2\right)$ as references and coupling constants were reported in Hz. HRESIMS data were collected with a LCT Premier time of flight mass spectrometer (Waters Corp., Milford, MA). Column chromatography was performed on CombiFlash columns (Teledyne Isco, Lincoln, NE). Normal-phase silica gel G TLC plates (w/UV 254) and reversed-phase $\mathrm{C}_{18}$ TLC plates (w/UV 254) (Sorbent Technologies, Atlanta, GA) were used for fraction and compound detection. The spots were visualized using UV light at $254 \mathrm{~nm}$ and spraying with $10 \% \mathrm{EtOH}$-sulfuric acid reagent. Semi-preparative HPLC was performed on an Agilent 1200 unit equipped with a DAD detector, utilizing a Lichrospher RP-18 column $(250 \times 10 \mathrm{~mm}, 5 \mu \mathrm{m})$.

\subsection{Plant material}

Above-ground biomass of J. caulescens var. bipinnatifida was collected by Luis González in the Cordillera de Santa Ana, in the vicinity of La Serena (latitude: $29^{\circ} 48^{\prime} 3$ S; longitude: $70^{\circ} 2^{\prime} 7 \mathrm{~W}$ ), Coquimbo (IV region), Chile on Jan. 15, 1995. The plant was authenticated by Gloria Montenegro of Pontificia Universidad Católica de Chile (P. U. C.). A voucher specimen, 0561, was deposited in the Herbarium of the P. U. C. Intellectual Property Agreements were signed by the collaborating institutions and deposited at the National Institutes of Health. 


\subsection{Extraction and isolation}

The collected biomass was air dried, ground to a coarse powder (475 g) and stored in an airtight dark container until processing time. It was extracted three times with $\mathrm{CH}_{2} \mathrm{Cl}_{2}-\mathrm{MeOH}$ $(50: 50,2.0 \mathrm{~L})$ at room temperature. After removing the solvents under vacuum, the extract $\left(50 \mathrm{~g}\right.$ ) was suspended in $300 \mathrm{~mL} \mathrm{H}_{2} \mathrm{O}$, followed by successive partitions with $n$-hexane, dichloromethane and $n$-butanol $(3 \times 300 \mathrm{~mL})$. The resulting $\mathrm{CH}_{2} \mathrm{Cl}_{2}$ fraction $(7.5 \mathrm{~g})$ collected was applied to a CombiFlash column (220 g silica gel) and eluted subsequently with a mixture of hexane-acetone (95:5, 90:10, 80:20, 67:33, 50:50, 33:67), in order of increasing concentrations of acetone.

The $20 \%$ acetone fraction $(750 \mathrm{mg}$ ) was subjected to CombiFlash CC ( $40 \mathrm{~g}$ silica gel), eluted with $\mathrm{CH}_{2} \mathrm{Cl}_{2}$ :EtOAc (10:1, 6:1, and 4:1) with decreasing amounts of $\mathrm{CH}_{2} \mathrm{Cl}_{2}$ to afford two fractions. Fraction $1(120 \mathrm{mg})$ was subjected to CombiFlash CC (24 g silica gel), eluted with hexane:EtOAc (1:1) to afford a fraction of the major compound. This fraction was subjected to semi-HPLC, eluted by isocratic $\mathrm{CH}_{3} \mathrm{CN}$ (38\%) to afford 2,3dihydrotrechonolide A $(\mathbf{1}, 42 \mathrm{mg})$. Fraction $2(140 \mathrm{mg})$ was subjected to CombiFlash CC (24 g silica gel), eluted with hexane:EtOAc (1:1) to afford a withanolide-containing fraction. This fraction was subjected to semi-HPLC, eluted by isocratic $\mathrm{CH}_{3} \mathrm{CN}(41 \%)$ to afford trechonolide A (3,15 mg).

The $33 \%$ acetone fraction $(890 \mathrm{mg}$ ) was subjected to CombiFlash CC ( $80 \mathrm{~g}$ silica gel), eluted with $\mathrm{CH}_{2} \mathrm{Cl}_{2}$ :acetone (10:1, 5:1, and 3:1) with decreasing amounts of $\mathrm{CH}_{2} \mathrm{Cl}_{2}$ to afford two fractions. The first fraction $(150 \mathrm{mg})$ was subjected to CombiFlash CC $(24 \mathrm{~g}$ silica gel), eluted with $\mathrm{CH}_{2} \mathrm{Cl}_{2}$ :EtOAc (4:1) to afford 2,3-dihydro-21-hydroxytrechonolide A $(2,5 \mathrm{mg})$. The second fraction $(200 \mathrm{mg})$ was subjected to a CombiFlash CC (24 g silica gel), eluted with $\mathrm{CH}_{2} \mathrm{Cl}_{2}$ :EtOAc (3:1) to afford jaborosalactone $39(4,7 \mathrm{mg})$.

3.3.1. 2,3-dihydrotrechonolide A (1)—Cubic colorless crystals; $[a]^{25} \mathrm{D}^{-2.2}(c 0.1$, $\left.\mathrm{CHCl}_{3}\right) ; \mathrm{UV}\left(\mathrm{CHCl}_{3}\right) v_{\max }(\log \varepsilon) 225(4.25) \mathrm{nm}$; IR (neat) $v_{\max } 3328$ (br), 2943, 2833, $1748,1712,1446,1018 \mathrm{~cm}^{-1}$; HRESIMS $m / z$ 509.2500 [M+Na] ${ }^{+}$(calcd for $\mathrm{C}_{28} \mathrm{H}_{38} \mathrm{O}_{7} \mathrm{Na}$, 509.2515); ${ }^{1} \mathrm{H}$ NMR and ${ }^{13} \mathrm{C}$ NMR, see Tables 1.

\subsubsection{Single-Crystal X-ray structure determination of 2,3-dihydrotrechonolide}

A (1)-Crystal analysis was performed with a colorless cubic crystal (dimensions $0.20 \times$ $\left.0.19 \times 0.12 \mathrm{~mm}^{3}\right)$ obtained from $\mathrm{CH}_{2} \mathrm{Cl}_{2}-\mathrm{CH}_{3} \mathrm{CN}(1: 1)$ using $\mathrm{Cu} \mathrm{K} a$ radiation $(\lambda=1.54178$ $\AA$ ) on a Bruker APEX2 diffractometer equipped with a Bruker MicroStar microfocus rotating anode X-ray source and Helios multilayer optics. Crystal data for $\mathbf{1}: \mathrm{C}_{28} \mathrm{H}_{38} \mathrm{O}_{7}$ (formula weight 486.58), Orthorhombic, space group $P 2{ }_{1} 2_{1}{ }_{2}, \mathrm{~T}=100(2) \mathrm{K}$, crystal cell parameters $a=11.1455(3) \AA, b=11.9845(4) \AA, c=18.3310(5) \AA, V=2448.53(12) \AA^{3}, D_{c}$ $=1.320 \mathrm{Mg} / \mathrm{m}^{3}, Z=4, \mathrm{~F}(000)=1048$, absorption coefficient $\mu=0.763 \mathrm{~mm}^{-1}$. A total of 17017 reflections were collected in the range $4.41<\theta<69.80^{\circ}$, with 4487 independent reflections $\left[R_{\text {(int) }}=0.0188\right]$, completeness to $\theta=66^{\circ}$ was $99.8 \%$. Multi-scan absorption correction applied; full-matrix least-squares refinement on $F^{2}$, the number of data/restraints/ parameters were 4487/0/469; goodness-of-fit on $F^{2}=1.041$; final $R$ indices $[I>2 \sigma(I)], R_{l}=$ $0.0248, \omega R^{2}=0.0650 ; R$ indices (all data), $R^{l}=0.0248, \omega R^{2}=0.0650$; largest difference peak and hole, 0.239 and $-0.159 \mathrm{e} / \AA^{-3}$.

3.3.3. 2,3-dihydro-21-hydroxytrechonolide A (2)-Solid; [a ${ }^{25} \mathrm{D}-0.8\left(c 0.1, \mathrm{CHCl}_{3}\right)$; $\mathrm{UV}\left(\mathrm{CHCl}_{3}\right) \lambda_{\max }(\log \varepsilon) 225$ (3.88) nm; IR (neat) $v_{\max } 3323$ (br), 2943, 2832, 1737, 1708, $1449,1021 \mathrm{~cm}^{-1}$; HRESIMS m/z $525.2484[\mathrm{M}+\mathrm{Na}]^{+}$(calcd for $\left.\mathrm{C}_{28} \mathrm{H}_{38} \mathrm{O}_{8} \mathrm{Na}, 525.2464\right) ;{ }^{1} \mathrm{H}$ NMR and ${ }^{13} \mathrm{C}$ NMR, see Tables 1 . 


\section{Supplementary Material}

Refer to Web version on PubMed Central for supplementary material.

\section{Acknowledgments}

The authors thank Mr. Luis González for the collection of the plant material. This fieldwork was supported by the ICBG Project "Bioactive Agents from Dryland Biodiversity in Latin America" grant 5 UO1 TW 00316-10 from the National Institutes of Health (NIH) Fogarty International Center (FIC) to B.N.T., whereas the chemical work was supported by KU Grant 2506014-910/099 to B.N.T. The authors are grateful to National Science Foundation (NSF) MRI grant CHE-0923449, which was used to purchase a Bruker APEX2 X-ray diffractometer and the software. The contents are solely the responsibility of the authors and do not necessarily represent the official views of the NIH/ FIC and NSF.

\section{References}

Chen LX, Hao H, Qiu F. Natural withanolides: an overview. Nat Prod Rep. 2011; 28:705-740. [PubMed: 21344104]

Lavie D, Besalle R, Pestchanker MJ, Gottlieb HE, Frolow F, Giordano OS. Trechonolide A, a new withanolide type from Trechonaetes laciniata. Phytochemistry. 1987; 26:1791-1795.

Misico RI, Nicotra VE, Oberti JC, Barboza G, Gil RR, Burton G. Withanolides and related steroids. Prog Chem Org Nat Prod. 2011; 94:127-229. [PubMed: 21833839]

Nicotra VE, Gil RR, Oberti JC, Burton G. Withanolides with phytotoxic activity from Jaborosa caulescens varcaulescens and J caulescens var bipinnatifida. J Nat Prod. 2007; 70:808-812. [PubMed: 17428092]

Samadi AK, Tong X, Mukerji R, Zhang H, Timmermann BN, Cohen MS. Withaferin A, a cytotoxic steroid from Vassobia breviflora, induces apoptosis in human head and neck squamous cell carcinoma. J Nat Prod. 2010; 73:1476-1481. [PubMed: 20726569]

Su BN, Park EJ, Nikolic D, Vigo JS, Graham JG, Cabieses F, Van Breemen RB, Fong HHS, Farnsworth NR, Pezzuto JM, Kinghorn AD. Isolation and characterization of miscellaneous secondary metabolites of Deprea subtriflora. J Nat Prod. 2003; 66:1089-1093. [PubMed: 12932130]

Tong X, Zhang H, Timmermann BN. Chlorinated withanolides from Withania somnifera. Phytochemistry Lett. 2011; 4:411-414.

Zhang H, Samadi AK, Gallagher RJ, Araya JJ, Tong X, Day VW, Cohen MS, Kindscher K, Gollapudi R, Timmermann BN. Cytotoxic withanolides constituents of Physalis longifolia. J Nat Prod. 2011; 74:2532-2544. [PubMed: 22098611]

Zhang H, Samadi AK, Cohen MS, Timmermann BN. Antiproliferative withanolides from the Solanaceae: A structure-activity study. Pure Appl Chem. 2012a; 84:1353-1367. [PubMed: 24098060]

Zhang H, Motiwala H, Samadi A, Day V, Aubé J, Cohen M, Kindscher K, Gollapudi R, Timmermann B. Minor withanolides of Physalis longifolia: structure and cytotoxicity. Chem Pharm Bull. 2012b; 60:1234-1239. [PubMed: 23036966]

Zhang H, Bazzill J, Gallagher RJ, Subramanian C, Grogan PT, Day VW, Kindscher K, Cohen MS, Timmermann BN. Antiproliferative withanolides from Datura wrightii. J Nat Prod. 2013; 76:445449. [PubMed: 23252848] 


\section{Highlights}

- Four withanolides 1-4 were isolated from Jaborosa caulescens var. bipinnatifida (Solanaceae).

- 2,3-dihydrotrechonolide A (1) and 2,3-dihydro-21-hydroxytrechonolide A (2) are new and uncommon.

- The structure of withanolide $\mathbf{1}$ was confirmed by X-ray crystallographic analysis. 

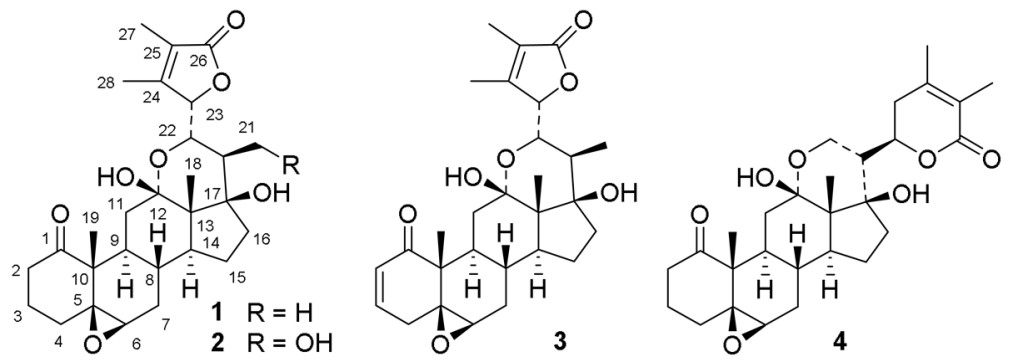

Fig. 1.

Withanolides 1-4 isolated from Jaborosa caulescens var. bipinnatifida 


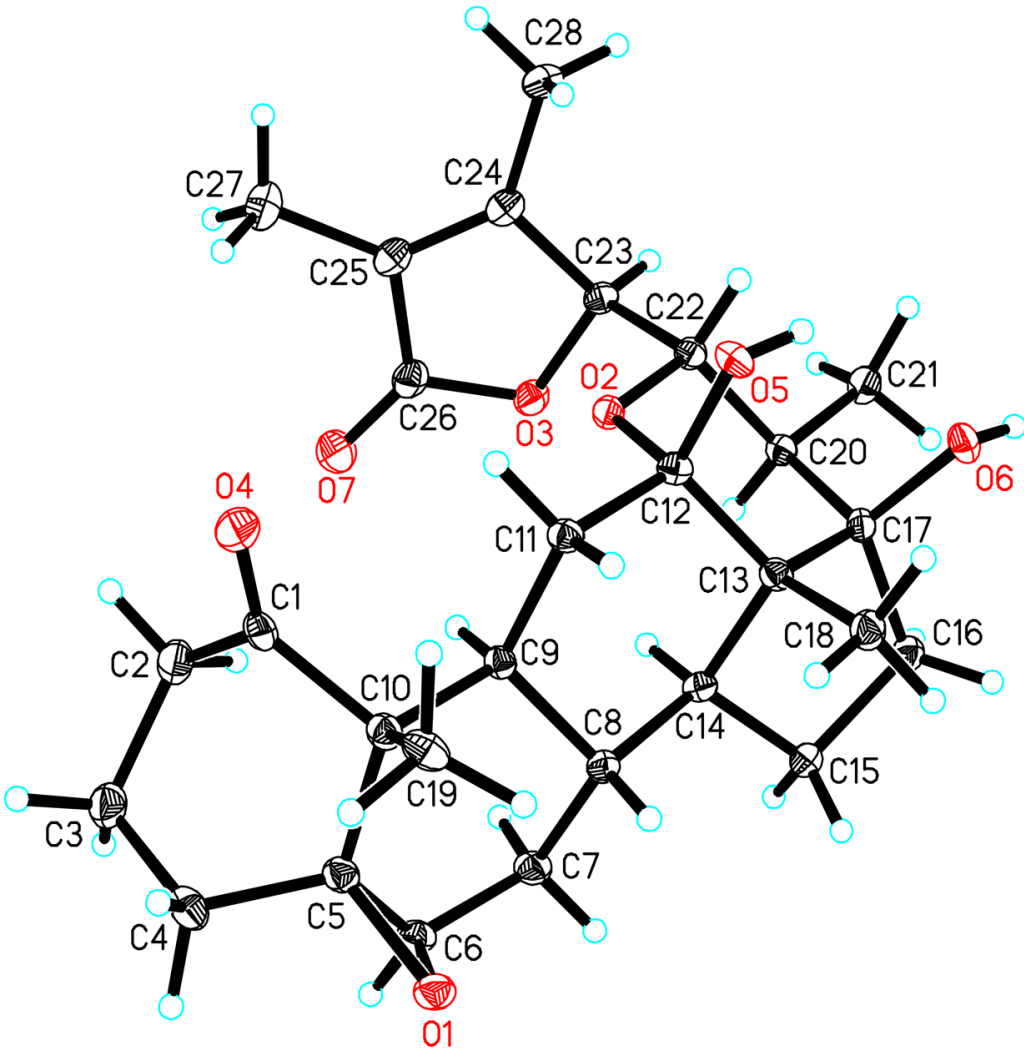

Fig. 2.

X-ray ORTEP drawing of 2,3-dihydrotrechonolide A (1) 


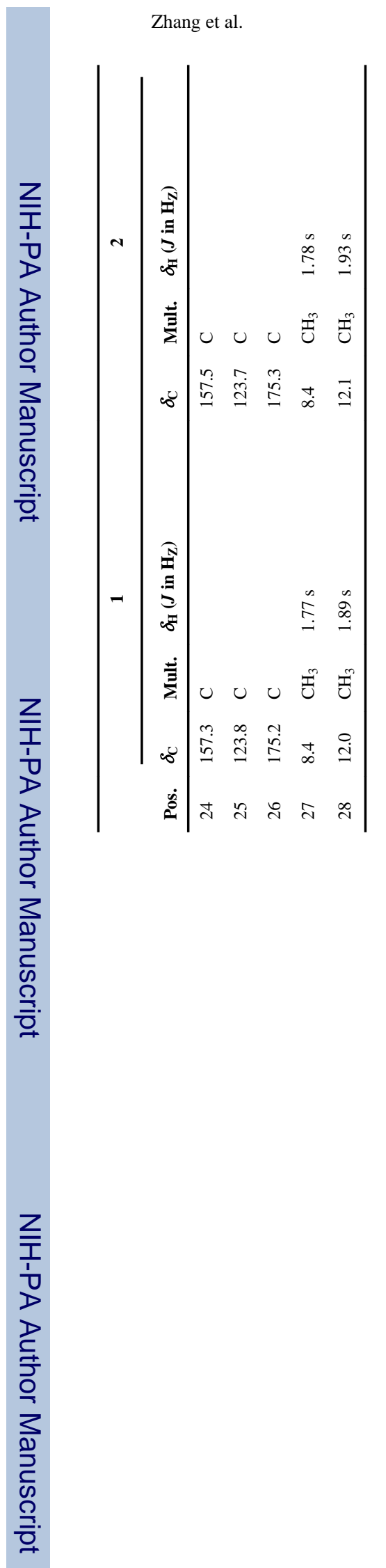

Phytochemistry. Author manuscript; available in PMC 2015 February 01. 